\title{
Composição química da forragem e do ensilado de azevém anual em função de diferentes tempos de secagem e estádios fenológicos
}

[Chemical composition of annual ryegrass forage and silage for different drying times and phenological phases]

\author{
A.C. Fluck ${ }^{1}$, J. Schafhäuser Júnior ${ }^{2}$, H. Alfaya Júnior ${ }^{3}$, O.A.D. Costa ${ }^{1}$, G.D. Farias ${ }^{4}$, \\ R.B. Scheibler ${ }^{3}$, F.A. Rizzo ${ }^{5}$, J.A.S. Manfron ${ }^{3}$, V.I. Fioreze ${ }^{3}$, D.C. Rösler ${ }^{3}$ \\ ${ }^{1}$ Universidade Tecnológica Federal do Paraná, Dois Vizinhos, Paraná \\ ${ }^{2}$ Embrapa Clima Temperado - Pelotas, RS \\ ${ }^{3}$ Universidade Federal de Pelotas - Pelotas, RS \\ ${ }^{4}$ Universidade Federal do Rio Grande do Sul, Porto Algre, RS \\ ${ }^{5}$ Universidade de Caxias do Sul, Caxias do Sul, RS
}

\begin{abstract}
RESUMO
O objetivo do presente estudo foi determinar como o tempo de secagem e o estádio fenológico da planta influenciam na composição química e qualidade da silagem de azevém (Lolium multiflorum, Lam.). O delineamento experimental foi de blocos ao acaso, com seis tratamentos (vegetativo: cortar e ensilar; cortar + pré-secagem de 4 horas e ensilar; cortar + pré-secagem de 7 horas e ensilar; pré-florescimento: ensilagem, cortar e ensilar e pré-secagem de 4 horas; florescimento: cortar e ensilar) e quatro repetições, com quatro meses de conservação da silagem. Foram determinados: desaparecimento de massa após o corte, rendimento de massa seca, proteína bruta e frações fibrosas. Além disso, foram determinados na silagem: $\mathrm{pH}$, lipídios totais, nitrogênio insolúvel em detergente neutro e ácido. $\mathrm{O}$ manejo empregado auxilia na desidratação da forragem, com perda na quantidade de nitrogênio no vegetativo. No préflorescimento, essa perda não ocorre. O avanço do ciclo da forrageira ocasiona diminuição na quantidade de nutrientes na biomassa, entretanto a produção de forragem é aumentada. A silagem apresentou composição bromatológica semelhante à observada na massa verde de azevém, o que demonstra a eficiência do método de conservação. A ensilagem em estádios mais avançados é aconselhada quando se busca maior quantidade de biomassa ensilada, porém com qualidade inferior.
\end{abstract}

Palavras-chave: silagem de pré-secado, forrageira hibernal, Lolium multiflorum

\section{ABSTRACT}

The aim was how to define the effect of pre-drying time and the plant phase's influence on chemical composition and quality of ryegrass silage. The experimental design was randomized blocks with six treatments (Vegetative: Cut and ensiled; cut + pre-drying 4 hours and ensiled and; cut + pre-drying of 7 hours and ensiled; Pre-flowering: Silage cutting and ensiled and pre-drying 4 hours Flowering:. cut and ensiled) and four repetitions. The silage was stowed for four months. It were determined the mass disappearance after cutting, dry matter yield, crude protein and fiber fractions. Moreover, it was determined on silage $\mathrm{pH}$, total lipids and insoluble protein content. The management used aids in dehydration of fodder, resulting in losses on the amount of nitrogen on vegetative phase. For preflowering, this loss has not occur. The advance of fodder cycle causes a decrease in the amount of nutrients in biomass, but fodder yield increased. Ryegrass silage presented chemical composition similar to that observed on green mass of ryegrass, evinced the efficiency of fodder conservation method. The silage in more advanced phases is advised when seeking greater amount of ensiled biomass, but lower quality.

Keywords: silage pre-dried, winter fodder, Lolium multiflorum

Recebido em 4 de maio de 2017

Aceito em 12 de janeiro de 2018

E-mail: anacarolinafluck@yahoo.com.br 


\section{Fluck et al.}

\section{INTRODUÇÃO}

Forragens conservadas são utilizadas como opção para garantir a alimentação e a estabilidade da produção animal nos momentos de déficit forrageiro nos diferentes sistemas de produção de ruminantes. Dentro desse contexto, o azevém (Lolium multiflorum Lam.) desponta como opção ótima e viável de manter a dieta de sistemas com alto padrão nutricional. É uma forrageira que apresenta alta qualidade nutricional quando comparada a outras forrageiras hibernais (Fontaneli et al., 2012), fator esse que está ligado aos seus altos teores de proteína e baixo conteúdo de carboidratos estruturais.

Por demonstrar alto teor de umidade, a biomassa verde de azevém pode apresentar alguns problemas quando ensilada. Segundo Kung (2002), realizar esse procedimento sem tempo prévio de secagem irá aumentar o escoamento de efluentes e, consequentemente, a perda de nutrientes digestíveis. Esse processo é diretamente influenciado pelo estágio fenológico da forrageira. Como possui alta proporção de folhas e colmos finos (Oliveira et al., 2015), a massa ceifada de azevém pode apresentar elevada taxa de desidratação, fazendo, assim, que tenha curto período de tempo em secagem a campo, o que proporciona menores perdas de nutrientes (Pereira e Reis, 2001).

Além disso, o avanço do ciclo da planta resulta no aumento dos teores de matéria seca na forragem, o que pode diminuir o tempo de secagem ou até a necessidade deste, conforme o avanço da idade da planta. Todavia, a idade da planta pode influenciar negativamente no conteúdo de nutrientes da planta e na elevação da quantidade de carboidratos estruturais (Van Soest, 1994).

No entanto, informações sobre o efeito de tempos de secagem no conteúdo de nutrientes em massas ensiladas de azevém são escassas. Assim, o objetivo foi determinar como o tempo de secagem e o ciclo fisiológico da planta influenciam na composição química e na qualidade da silagem de azevém anual.

\section{MATERIAL E MÉTODOS}

A implantação do azevém foi realizada em abril de 2013, em área experimental pertencente à
Embrapa Clima Temperado - Estação Terras Baixas, situada na cidade de Capão do Leão. Foi realizada semeadura em linha, com densidade de $20 \mathrm{~kg} \cdot \mathrm{ha}^{-1}$ de sementes puras viáveis. O solo é classificado como Planossolo Háplico Eutrófico solódico, pertencente à unidade de mapeamento Pelotas (Streck et al., 2008). O clima da região é o subtropical úmido (Cfa), segundo classificação de Köppen.

O solo foi devidamente preparado com aração e duas gradagens, corrigido e adubado, conforme recomendação da Rede Oficial de Laboratórios de Análise de Solos e Tecidos Vegetais dos Estados do Rio Grande do Sul e Santa Catarina (Rolas) para pastagens hibernais, seguindo a análise de solo. A adubação de cobertura foi realizada com aplicação de $80 \mathrm{~kg} \cdot \mathrm{ha}^{-1}$ de N. A uniformização do dossel forrageiro foi feita com corte a $7 \mathrm{~cm}$ do solo (Oliveira et al., 2015), quando as plantas atingiram $30 \mathrm{~cm}$ de altura, e foram adicionados $100 \mathrm{~kg} \cdot \mathrm{ha}^{-1}$ de $\mathrm{N}$ após o corte.

O delineamento experimental foi de blocos completos ao acaso, com seis tratamentos (vegetativo, com 0, 4 e 7 horas de pré-secagem; pré-florescimento, com 0 e 4 horas de présecagem; e florescimento) e quatro repetições. Ao alcançar novamente altura de $30 \mathrm{~cm}$, foi realizado corte para a ensilagem no estádio vegetativo. No momento em que as plantas entraram em pré-florescimento, com $20 \%$ de aparecimento de inflorescências, foi realizado corte para a ensilagem nas parcelas desse estádio. Da mesma forma, quando as parcelas restantes entraram em florescimento pleno, estimando-se $20 \%$ de espiguetas com grãos formados, foi feito o corte e a ensilagem do material.

Para a confecção dos microssilos no vegetativo, pelo alto teor de umidade, foram determinados três diferentes tempos de secagem (cortar e ensilar; cortar e pré-secagem de 4 horas e ensilar; e cortar e pré-secagem de 7 horas e ensilar); para o pré-florescimento, foram determinados dois tempos de secagem (ensilagem logo após o corte e pré-secagem de 4 horas); e no florescimento pleno, pelo baixo teor de umidade, não houve pré-secagem, sendo realizada a ensilagem do material logo após o corte.

O material verde foi picado em partículas de aproximadamente $5 \mathrm{~cm}$, utilizando-se picador estacionário, ensilado em microssilos 
experimentais de de PVC, com densidade de $650 \mathrm{~kg} \mathrm{~m}^{-3}$ de MS em todos os estádios, e armazenado. Após quatro meses de cada ensilagem, os microssilos foram abertos, e foram retiradas subamostras para análises da composição química. Para a determinação do pH, foi utilizada a metodologia descrita por Silva e Queiroz (2002), com o auxílio de um potenciômetro.
Em paralelo, foi realizada a curva de desidratação das plantas nos três estádios fenológicos. Foram cortadas amostras do dossel em quadro de $0,25 \mathrm{~m}^{2}$, e estas foram deixadas expostas a campo para que ocorresse desidratação natural. As amostras foram recolhidas a partir das 10 horas, nos tempos 1,5; 3; 4,5; 6 e 7,5 horas após o corte, e calculou-se o percentual de perda de massa durante a exposição às condições climáticas (Fig. 1).

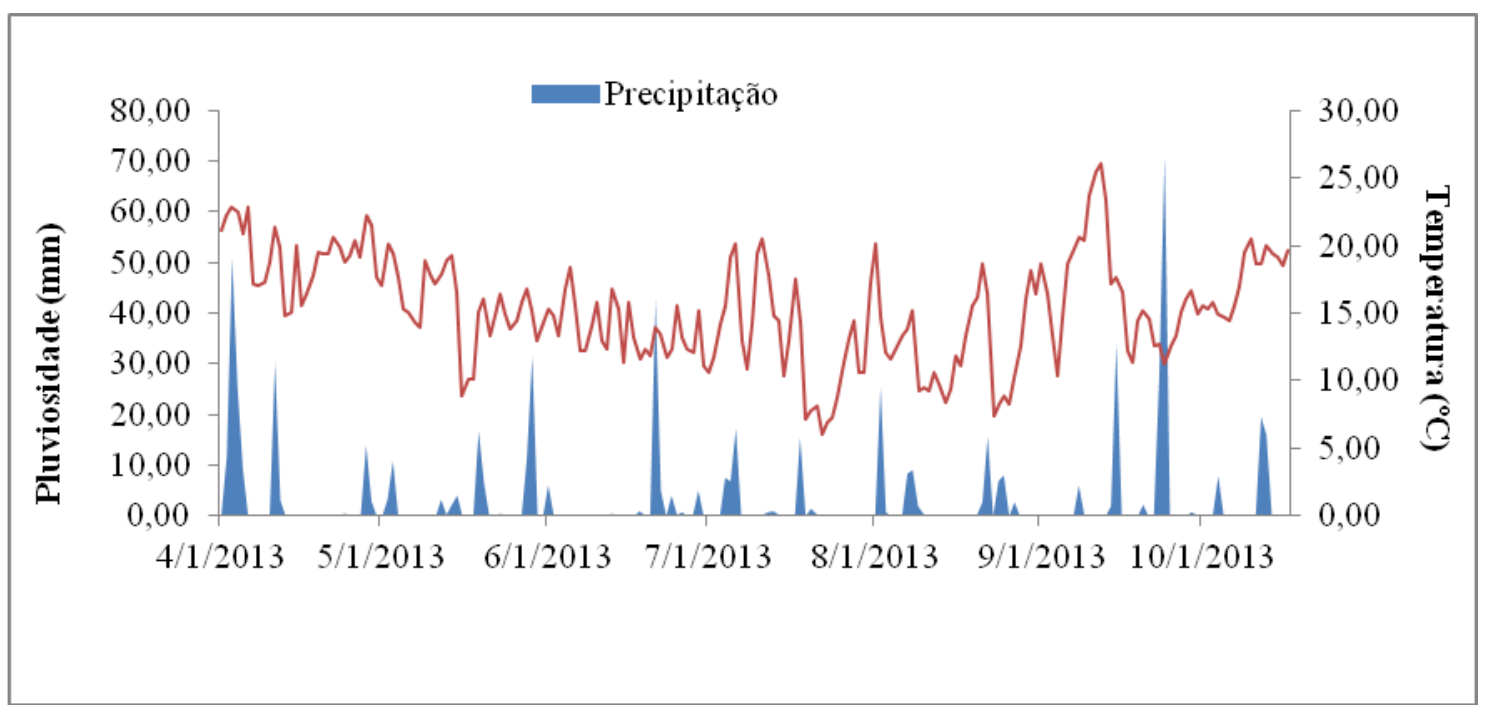

Figura 2. Temperatura média e precipitação diária, nos meses de abril a outubro de 2013. Estação Agroclimatológica de Pelotas, RS.

Análises químicas foram feitas nas amostras de silagem dos microssilos e em amostras de azevém, cortadas em $0,25 \mathrm{~m}^{2}$ no campo. Para a determinação da matéria pré-seca (MPS), as amostras foram levadas à estufa de circulação forçada de ar a $55^{\circ} \mathrm{C}$, por 72 horas. Os teores de matéria seca total (MST) foram determinados por secagem em estufa a $105^{\circ} \mathrm{C}$, e a matéria mineral por queima em mufla. $\mathrm{O}$ teor de matéria orgânica (MO) foi calculado como 100 - matéria mineral (Método 942.05, Official Methods of Analysis, 1998).

Os teores de fibra em detergente neutro (FND) e fibra em detergente ácido (FDA) foram feitos conforme Van Soest (1963), adaptado por utilizar saquinhos de poliéster (KOMAREK, 1993), submetidos a autoclavagem por 40 minutos a $110^{\circ} \mathrm{C}$ (SENGER et al.; 2008). Lignina em detergente ácido (LDA) foi determinada com tratamento em ácido sulfúrico 72\% (método 973.18, AOAC, 1997). A proteína bruta foi estimada através do teor de nitrogênio total $(\mathrm{N})$ foi estimado pelo método de Kjeldahl (método 984.13, Official Methods of Analysis, 1995), modificado por usar solução de ácido bórico 5\% (p/v) como receptor da amônia livre durante a destilação, e solução padrão de ácido sulfúrico para titulação. Os teores de nitrogênio solúvel em detergente neutro (NIDN), nitrogênio não proteico e nitrogênio insolúvel em detergente ácido (NIDA) foram estimados de acordo com Licitra et al. (1996).

Os dados foram submetidos à análise de variância e, em caso de diferença significativa entre as médias, foram comparados em nível de $5 \%$ de significância pelo teste DMS de Fisher.

\section{RESULTADOS E DISCUSSÃO}

Houve melhora nas características qualitativas da biomassa de azevém com o uso do corte de emparelhamento. Ocorreu aumento significativo 


\section{Fluck et al.}

nos teores de PB e MM, e diminuição da MST, FDN e FDA, (Tab. 1). Também foi observado aumento no rendimento de matéria seca, em relação à altura em que foram realizados os cortes. Pinto et al. (2001) relatam que, após realizado o corte, o aumento do perfilhamento é estimulado pela maior incidência de luz nas gemas presentes nas partes inferiores da planta, o que resulta em taxas maiores de expansão e aparecimento de folha e consequente maior produção de biomassa.

Tabela 1. Teores de matéria seca total (MST), matéria mineral (MM) e orgânica (MO), proteína bruta (PB), fibra em detergente neutro (FDN) e ácido (FDA) e rendimento de massa seca (RMS) de biomassa de azevém no corte antes e após a uniformização. Embrapa Clima Temperado, Capão do Leão-RS, 2013

\begin{tabular}{cccccccc}
\hline & MST & MO & MM & PB & FDN & FDA & RMS \\
\hline Uniformização & $21,16^{\mathrm{a}}$ & $89,96^{\mathrm{a}}$ & $10,04^{\mathrm{b}}$ & $16,22^{\mathrm{b}}$ & $39,07^{\mathrm{a}}$ & $30,62^{\mathrm{a}}$ & $1452,8^{\mathrm{b}}$ \\
Corte tempo 0 & $14,38^{\mathrm{b}}$ & $88,32^{\mathrm{b}}$ & $11,68^{\mathrm{a}}$ & $19,63^{\mathrm{a}}$ & $36,98^{\mathrm{b}}$ & $22,21^{\mathrm{b}}$ & $2055,4^{\mathrm{a}}$ \\
\hline
\end{tabular}

Médias seguidas da mesma letra na coluna não diferem significativamente entre si pelo teste $\mathrm{F}(\mathrm{P}<0,05)$.

Esse aumento de folhas no dossel resulta na diminuição dos teores de carboidratos não solúveis totais e, consequentemente, elevação de MM e PB na forrageira, conferindo ao alimento melhor qualidade nutricional. Isso vai de encontro a Van Soest (1994), que descreve que, em pastagens, as folhas possuem menores concentrações de FDN, FDA e LDA em comparação aos colmos, o que indica que, após o corte, por haver um maior perfilhamento $\mathrm{e}$, consequentemente, um maior número de folhas, essas concentrações devem ser menores.

De acordo com Vanbelle et al. (1983), a técnica de pré-secagem para silagem consiste em cortar a forrageira, seguindo o pré-emurchecimento, até que o material atinja de 30 a $45 \%$ de massa seca, recolhida dentro do silo e compactada. O desaparecimento de massa foi crescente no período avaliado (Fig. 2), com tendência à estabilização após seis horas de exposição, próximo às 17 horas. Isto ocorre devido à diminuição da temperatura e da luminosidade ocorrida nesse horário. A perda de água, mesmo em condições ambientais ótimas, não é uniforme. $O$ período de secagem pode ser dividido em duas ou três fases, as quais diferem na duração, na taxa de perda de água e na resistência à desidratação (MacDonald e Clark, 1987). Na primeira fase, há rápida desidratação da forragem logo após o corte, reduzindo a umidade de $80-85 \%$ para $65-60 \%$, sendo a perda de água por transpiração pelos estômatos.

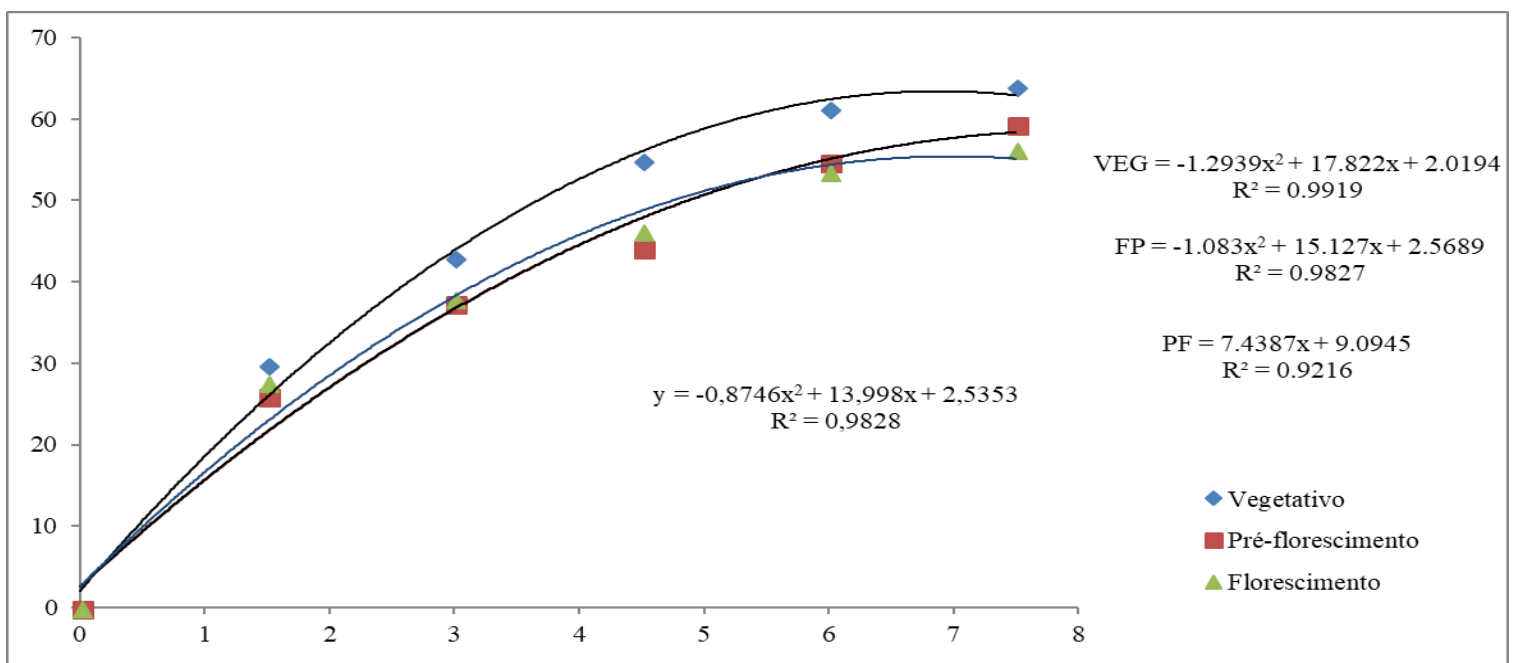

Figura 2. Percentual de desidratação da massa verde de 0 a 7,5 horas em diferentes estádios fenológicos. 
A segunda fase é marcada pelo fechamento dos estômatos, ocorrendo a desidratação por difusão celular através da epiderme e cutícula. Nessa fase, a umidade é reduzida de teores próximos a $60 \%$ para teores ao redor de $30 \%$. Já na terceira fase, a perda de umidade se dá por meio de plasmólise, em que ocorre redução na umidade de $30 \%$ para 10 a $15 \%$ (Harris e Tullberg, 1980; Lavezzo e Andrade, 1994). Pereira e Reis (2001) descrevem que as folhas das gramíneas perdem água 15 vezes mais rápido que os caules, sendo $25 \%$ da umidade dos caules perdida através das folhas. Neres et al. (2011) destacam que a taxa de secagem pode variar de acordo com as características estruturais da forrageira, especialmente espessura do colmo, razão folha/colmo, o que interfere no tempo de secagem e no teor final de matéria seca.

O tempo de desidratação auxiliou no aumento dos teores de MST da massa verde no estádio vegetativo, o que tende a contribuir para a adequada fermentação do ensilado (Tab. 2). Já no pré-florescimento, não houve diferença significativa tanto entre os teores de MST em 0 e 4 horas quando comparados esses horários com o florescimento. Isso demonstra que a desidratação não afeta o teor de umidade neste estádio. Com o desenvolvimento das plantas, foi observada diminuição no seu valor nutricional e no conteúdo de água.

Tabela 2. Teores de matéria seca total (MST), matéria mineral (MM) e orgânica (MO), proteína bruta (PB), fibra em detergente neutro (FDN) e ácido (FDA), lignina em detergente ácido (LDA) e rendimento de massa seca (RMS) de biomassa pré-ensilada de azevém com diferentes tempos de desidratação e diferentes estádios fenológicos. Embrapa Clima Temperado, Capão do Leão-RS, 2013

\begin{tabular}{|c|c|c|c|c|c|c|c|}
\hline & \multicolumn{3}{|c|}{ Vegetativo } & \multicolumn{2}{|c|}{ Pré-florescimento } & \multirow{2}{*}{$\begin{array}{c}\text { Florescimento } \\
0\end{array}$} & \multirow[b]{2}{*}{$\mathrm{R}^{2}$} \\
\hline & 0 & 4 & 7 & 0 & 4 & & \\
\hline $\mathrm{MST}^{* *}$ & $14,38^{\mathrm{d}}$ & $25,29^{c}$ & $32,12^{\mathrm{b}}$ & $51,09^{\mathrm{a}}$ & $48,58^{\mathrm{a}}$ & $48,82^{\mathrm{a}}$ & 0,94 \\
\hline $\mathrm{MM}^{*}$ & $11,68^{\mathrm{a}}$ & $8,62^{\mathrm{b}}$ & $8,55^{\mathrm{b}}$ & $8,55^{\mathrm{b}}$ & $7,55^{\mathrm{c}}$ & $7,02^{\mathrm{c}}$ & 0,88 \\
\hline MO* & $88,32^{\mathrm{c}}$ & $91,38^{\mathrm{b}}$ & $91,45^{\mathrm{b}}$ & $91,45^{\mathrm{b}}$ & $92,45^{\mathrm{b}}$ & $92,98^{\mathrm{a}}$ & 0,88 \\
\hline $\mathrm{PB}^{*}$ & $19,63^{\mathrm{a}}$ & $16,64^{\mathrm{b}}$ & $15,23^{\mathrm{c}}$ & $12,20^{\mathrm{d}}$ & $11,08^{\mathrm{e}}$ & $7,67^{\mathrm{f}}$ & 0,99 \\
\hline kg de PB.ha ${ }^{-1}$ & $403,5^{\mathrm{b}}$ & $425,1^{\mathrm{b}}$ & $411,7^{\mathrm{b}}$ & $673,6^{\mathrm{a}}$ & $597,5^{\mathrm{a}}$ & $438,3^{\mathrm{b}}$ & 0,85 \\
\hline FDN* & $36,98^{\mathrm{d}}$ & $37,87^{\mathrm{d}}$ & $38,72^{\mathrm{cd}}$ & $40,15^{\mathrm{c}}$ & $42,58^{\mathrm{b}}$ & $53,52^{\mathrm{a}}$ & 0,96 \\
\hline FDA* & $22,21^{\mathrm{c}}$ & $22,22^{\mathrm{c}}$ & $23,66^{\mathrm{bc}}$ & $23,82^{\mathrm{bc}}$ & $24,84^{\mathrm{b}}$ & $34,98^{\mathrm{a}}$ & 0,93 \\
\hline LDA* & $4,04^{\mathrm{c}}$ & $4,30^{\mathrm{c}}$ & $4,35^{\mathrm{c}}$ & $5,35^{\mathrm{b}}$ & $5,72^{\mathrm{b}}$ & $8,23^{\mathrm{a}}$ & 0,91 \\
\hline RMS (kg.ha $\left.{ }^{-1}\right)$ & $2055,4^{\mathrm{c}}$ & $2554,7^{\mathrm{b}}$ & $2703,3^{\mathrm{b}}$ & $5521,1^{\mathrm{a}}$ & $5392,3^{\mathrm{a}}$ & $5714,9^{\mathrm{a}}$ & 0,80 \\
\hline
\end{tabular}

Médias seguidas da mesma letra na linha não diferem significativamente entre si pelo teste de Fisher $(\mathrm{P}<0,05)$; *valores expressos em porcentagem da massa seca total; **valores expressos em porcentagem da massa verde.

Pereira e Reis (2001) comentam que, do ponto de vista de desidratação, o avanço no estádio de desenvolvimento resulta em vantagem para o processo de perda de água, mas é prejudicial em termos de qualidade da forragem. O teor de matéria orgânica foi maior no florescimento (Tab. 2). Todavia, o menor valor desta variável foi encontrado no tempo 0 do vegetativo. Geralmente, plantas jovens possuem parede celular menos espessa e maior conteúdo intracelular. Com a maturidade, há aumento da produção de matéria seca por unidade de área, havendo, porém, diminuição do valor nutritivo do azevém devido a alterações na estrutura das plantas (Van Soest, 1994; Skonieski et al., 2011).
Entre as principais alterações estão o aumento na concentração de carboidratos fibrosos, tais como a celulose, a hemicelulose e a lignina, e, paralelamente, a diminuição do conteúdo celular (Pereira e Reis, 2001; Van Soest, 1994). Assim, maturidade é fator primário para o declínio da qualidade nutricional das plantas forrageiras, mesmo podendo ter influência de outros fatores sobre esta (Kozloski et al., 2005). Foi observado que os teores de proteína decaíram significativamente $(\mathrm{P}<0,05)$ com o avanço do ciclo da cultura e com o uso da desidratação (Tab. 2). 


\section{Fluck et al.}

A queda de aproximadamente $60 \%$ do teor de proteína na evolução fenológica da planta demonstra o efeito da maturação da planta na quantidade de nutrientes potencialmente digestíveis. Entretanto, se for levada em consideração a quantidade total de proteína na biomassa total (Tab. 2), o estádio de préflorescimento é superior aos demais. As frações fibrosas foram mais elevadas no florescimento e menores no vegetativo, independentemente do tempo de desidratação utilizado. Segundo Minson (1990), haverá redução dos teores proteicos nas forrageiras durante o processo de envelhecimento, que ocorre pelo aumento da proporção de talos, pela elevação dos teores de fibra e pela redução da proporção de folhas.

O rendimento de massa seca foi menor no tempo 0 do vegetativo, tendo o pré-florescimento e o florescimento obtido rendimento semelhante (Tab. 2). Em plantas com elevado teor de umidade, após o corte, os estômatos permanecem abertos até que a planta perca aproximadamente $20 \%$ da água de seus tecidos (Pereira e Reis, 2001). Em experimento realizado com aveia preta (Avena strigosa Schreb.), Berto e Mühlbach (1997) constataram que o emurchecimento resultou, em relação à forragem verde, em elevação dos teores de MS (15,3 para 31,2\%) e de carboidratos solúveis (2,9 para 3,3\%); portanto, pode-se dizer que a planta segue a produção de fotoassimilados até que ocorra o fechamento dos estômatos.

Para silagem, houve diferença significativa nos teores de MST entre os tempos de desidratação e estádios fenológicos (Tab. 3). Durante a fermentação, ocorre liberação de gases resultantes da degradação de compostos solúveis. Isso explica o comportamento dos teores de MO, da massa verde para a ensilada, principalmente, nos estádios vegetativo e pré-florescimento. Assim, a MO, na silagem, não apresentou diferença entre os tempos de desidratação do vegetativo e entre os tempos 4 e 7 deste estádio com os dois tempos do pré-florescimento. Griffths e Burns (2004) remetem ao fato de que forragens com teores de matéria seca abaixo de $30 \%$ podem resultar em ensilados com pouca fermentação.

Tabela 3. Teores de matéria seca total (MST), matéria mineral (MM) e orgânica (MO), fibra em detergente neutro (FDN) e ácido (FDA), lignina em detergente ácido (LDA) e lipídios totais (LT) na silagem de azevém advinda de diferentes tempos de desidratação e diferentes estádios fenológicos. Embrapa Clima Temperado, Capão do Leão-RS, 2013

\begin{tabular}{|c|c|c|c|c|c|c|c|}
\hline & \multicolumn{3}{|c|}{ Vegetativo } & \multicolumn{2}{|c|}{ Pré-florescimento } & \multirow{2}{*}{$\begin{array}{c}\text { Florescimento } \\
0\end{array}$} & \multirow[b]{2}{*}{$\mathrm{R}^{2}$} \\
\hline & 0 & 4 & 7 & 0 & 4 & & \\
\hline $\mathrm{MST}^{* *}$ & $13,87^{\mathrm{d}}$ & $25,14^{\mathrm{bc}}$ & $29,32^{\mathrm{b}}$ & $23,31^{\mathrm{c}}$ & $29,29^{\mathrm{b}}$ & $44,59^{\mathrm{a}}$ & 0,98 \\
\hline MM* & $10,84^{\mathrm{a}}$ & $10,02^{\mathrm{ab}}$ & $10,17^{\mathrm{ab}}$ & $10,63^{\mathrm{ab}}$ & $9,80^{\mathrm{b}}$ & $7,57^{\mathrm{c}}$ & 0,78 \\
\hline MO* & $89,16^{\mathrm{c}}$ & $89,88^{b c}$ & $89,83^{b c}$ & $89.37^{\mathrm{bc}}$ & $90,20^{\mathrm{b}}$ & $92,42^{\mathrm{a}}$ & 0,78 \\
\hline FDN* & $36,73^{d}$ & $36,92^{\mathrm{d}}$ & $38,19^{\mathrm{dc}}$ & $39.82^{\mathrm{c}}$ & $41,74^{\mathrm{b}}$ & $52,94^{\mathrm{a}}$ & 0,96 \\
\hline FDA* & $21,85^{\mathrm{d}}$ & $22,24^{\mathrm{cd}}$ & $23,36^{\mathrm{c}}$ & $23.86^{\mathrm{bc}}$ & $24,91^{\mathrm{b}}$ & $34,93^{\mathrm{a}}$ & 0,94 \\
\hline LDA* & $3,85^{\mathrm{c}}$ & $4,01^{\mathrm{c}}$ & $4,06^{\mathrm{c}}$ & $5.42^{\mathrm{b}}$ & $5,76^{\mathrm{b}}$ & $8,16^{\mathrm{a}}$ & 0,97 \\
\hline $\mathrm{LT}^{*}$ & $5,30^{\mathrm{a}}$ & $4,69^{\mathrm{a}}$ & $4,50^{\mathrm{ba}}$ & $3.64^{\mathrm{bc}}$ & $3,43^{\mathrm{bc}}$ & $3,55^{\mathrm{c}}$ & 0,60 \\
\hline
\end{tabular}

Médias seguidas da mesma letra na linha não diferem significativamente entre si pelo teste de Fisher $(\mathrm{P}<0,05)$; *valores expressos em porcentagem da matéria seca; **valores expressos em porcentagem da massa verde.

As frações fibrosas se comportaram de maneira semelhante à pré-ensilagem, com valores aumentando conforme o avanço do ciclo da forrageira (Tab. 3). Além disso, os valores apresentam pouca variação em comparação aos encontrados na pré-ensilagem. Quando gramíneas amadurecem, elas se tornam mais fibrosas e sua qualidade forrageira diminui rapidamente (Griffths e Burns, 2004), visto que 
isso se reflete na diminuição do teor de minerais, visualizado com o avanço do ciclo da planta.

Lopes et al. (2008), ao avaliarem silagens de triticale em diferentes idades de corte, observaram valores de 48,20 e $29,40 \%$ de FDN e FDA, valores esses que são superados apenas pelo estádio de florescimento. Os teores de lignina se mantiveram próximos aos encontrados por Hernández et al. (2002), de 5,35 e 5,29\% da MS, respectivamente, para silagens de milho sem e com inoculante.

A desidratação influenciou na concentração de proteína bruta da massa ensilada, que apresentou diminuição no teor desse nutriente com a murcha do material (Tab. 4). A degradação de compostos nitrogenados pode ocorrer durante a desidratação da planta após o corte, tendo liberação de amônia tanto no conteúdo celular, como visto nos resultados de $\mathrm{N}_{-} \mathrm{NH}_{3}$ (Tab. 4), quanto durante a fermentação dentro do silo. O ciclo da planta também influenciou no teor de proteína bruta do ensilado, uma vez que a concentração desse nutriente decaiu quase $64 \%$ entre o estádio vegetativo e o de florescimento. Devido à velocidade de desenvolvimento das gramíneas, com o aumento da idade, diminui a concentração de nutrientes no conteúdo celular, que passa a acumular nutrientes de menor digestibilidade, como FDN e FDA, em detrimento da PB (Mesquita e Neres, 2008).

Tabela 4. Teores de proteína bruta (PB), nitrogênio insolúvel em detergente neutro (NIDN) e ácido (NIDA), pH e nitrogênio amoniacal $\left(\mathrm{N}_{-} \mathrm{NH}_{3}\right)$ na silagem de azevém advinda de diferentes tempos de desidratação e diferentes estádios fenológicos. Embrapa Clima Temperado, Capão do Leão-RS, 2013

\begin{tabular}{lccccccc} 
& \multicolumn{3}{c}{ Vegetativo } & \multicolumn{2}{c}{ Pré-florescimento } & Florescimento \\
& 0 & 4 & 7 & 0 & 4 & 0 & $\mathrm{R}^{2}$ \\
\hline $\mathrm{PB}^{*}$ & $18,23^{\mathrm{a}}$ & $16,48^{\mathrm{b}}$ & $16,79^{\mathrm{b}}$ & $11,32^{\mathrm{c}}$ & $11,17^{\mathrm{c}}$ & $6,59^{\mathrm{d}}$ & 0,97 \\
$\mathrm{NIDN}^{*}$ & $0,60^{\mathrm{f}}$ & $0,68^{\mathrm{e}}$ & $0,78^{\mathrm{d}}$ & $0,87^{\mathrm{c}}$ & $0,95^{\mathrm{b}}$ & $1,06^{\mathrm{a}}$ & 0,97 \\
$\mathrm{NIDA}^{*}$ & $0,27^{\mathrm{d}}$ & $0,32^{\mathrm{c}}$ & $0,50^{\mathrm{b}}$ & $0,52^{\mathrm{b}}$ & $0,57^{\mathrm{a}}$ & $0,59^{\mathrm{a}}$ & 0,96 \\
$\mathrm{pH}$ & $3,78^{\mathrm{b}}$ & $4,20^{\mathrm{a}}$ & $4,33^{\mathrm{a}}$ & $3,67^{\mathrm{c}}$ & $3,76^{\mathrm{bc}}$ & $3,71^{\mathrm{bc}}$ & 0,80 \\
$\mathrm{~N}^{\mathrm{N}}$ & $7,72^{\mathrm{c}}$ & $12,21^{\mathrm{b}}$ & $15,48^{\mathrm{a}}$ & $6,98^{\mathrm{c}}$ & $13,09^{\mathrm{b}}$ & $12,16^{\mathrm{b}}$ & 0,87 \\
\hline
\end{tabular}

Médias seguidas da mesma letra na linha não diferem significativamente entre si pelo teste de Fisher $(\mathrm{P}<0,05)$; *valores expressos em porcentagem da matéria seca; **valores expressos em porcentagem do nitrogênio total.

Os teores de nitrogênio associado às frações fibrosas também aumentaram com o avanço do ciclo da planta, bem como com a desidratação (Tab. 4), fato que está de acordo com Blaser (1964), que descreve que os teores de NIDN, NIDA e FDN irão ser maiores com o avanço da maturidade da planta. Van Soest (1994) sugere que variações de 3 a $15 \%$ desta fração na massa seca estariam dentro da normalidade. Geralmente, os teores mais elevados de NIDA estão associados à formação de compostos de Maillard, em decorrência da elevação da temperatura nos silos (Evangelista et al., 2004).

No caso da desidratação, pode-se dizer que a fração proteica que oscilou foi a presente no conteúdo celular, já que está em moléculas mais reativas no citosol. Nos estádios fisiológicos, isto se deve ao aumento natural dos carboidratos estruturais com o avanço do ciclo da forrageira.
$\mathrm{O}$ pH sofreu elevação com a desidratação no estádio vegetativo, em que os níveis de $\mathrm{N}-\mathrm{NH}_{3}$ aumentaram nos tempos 4 e 7 (Tab. 4). Esse fato pode estar relacionado à concentração tanto de carboidratos solúveis e concentração de amônia quanto de concentração de minerais que, com a desidratação, foram proporcionalmente aumentados no conteúdo de água existente, atuando como tampão na silagem.

Nos estádios subsequentes, houve também aumento de amônia, entretanto o conteúdo de minerais foi menor, diminuindo o poder tampão da massa ensilada. Apesar dessas variações, os valores de $\mathrm{pH}$ encontrados estão em níveis adequados. Segundo Nussio et al. (2001), este deve estar entre 3,6 -4,5, pois valores nessa faixa são responsáveis pela inibição do crescimento de microrganismos anaeróbicos indesejáveis, como 


\section{Fluck et al.}

os do gênero Clostridium spp. Um bom processo de ensilagem é aquele capaz de promover rápida queda do $\mathrm{pH}$ da forrageira, propiciando ambiente anaeróbico e população satisfatória de bactérias produtoras de ácido lático (McDonald et al., 1991). Teores inferiores de nitrogênio amoniacal indicam menor intensidade da proteólise durante o processo de fermentação, como resultado da menor atuação de bactérias do gênero Clostridium (McDonald et al., 1991; Muck e Shinners, 2001) resultando em um material de melhor qualidade (Dórea et al., 2013). Entretanto, o teor de $\mathrm{N}-\mathrm{NH}_{3}$ aumentou com a utilização da desidratação e com o avanço do ciclo da forrageira, o que contraria a afirmação destes autores. Ainda, na classificação das silagens quanto ao teor de nitrogênio amoniacal em relação ao nitrogênio total, considera-se como: muito boa, quando os valores são inferiores a 10\%; aceitável, de 10 a 15\%; e insatisfatória, quando os valores se situam acima de 20\% (Woolford, 1984; McDonald et al., 1991).

\section{CONCLUSÕES}

A introdução do manejo de desidratação auxiliou na perda de umidade da forragem, com perda na quantidade de nitrogênio no estádio vegetativo. Já no pré-florescimento, essa perda não ocorre. A silagem apresentou composição química semelhante à observada na massa verde de azevém, demonstrando a eficiência do método de conservação. A confecção da silagem em estádios mais avançados é aconselhada quando se busca maior quantidade de biomassa ensilada, porém esta será de menor qualidade.

\section{REFERÊNCIAS}

BERTO, J.L.; MÜHLBACH, P.R.F. Silagem de aveia preta no estádio vegetativo, submetida à ação de inoculantes e ao efeito de emurchecimento. Rev. Bras. Zootec., v.26, p.651658, 1997.

BLASER, R.E. Symposium on forage utilization. Effects of fertility levels and stage of maturity on forage nutritive value. J. Anim. Sci., v.23, p.246253, 1964

DÓREA, J.R.R.; PEREIRA, L.G.R., FERREIRA, A.L., et al. Composição bromatológica e dinâmica da silagem de jaca. Semina: Cien.Agrár., v.34, p.1967-1976, 2013.
EVANGELISTA, A.R.; ABREU, J.G.; AMARAL, P.N.C.; et al. Produção de silagem de capim marandu (Brachiaria brizantha Stapf cv. Marandu) com e sem emurchecimento. Cienc. Agrotec., v.28, p.446- 452, 2004.

FONTANELI, R.S.; SANTOS, H.S.; FONTANELI, R.S. et al. Gramíneas forrageiras anuais de inverno. In: FONTANELI, R.S.; SANTOS, H.S.; FONTANELI, R.S. Forrageiras para integração lavoura-pecuária-floresta na região sul-brasileira. 2.ed. Brasília: Embrapa, 2012. 544p.

GRIFFTHS, N.W.; BURNS, H.M. Silage from pastures and forage crops. In: KAISER, A.G.; PILTZ, J.W.; GRIFFTHS, N.W. Successful silage. 2.ed. Orange: Dairy Australia \& NSW Dept. of Primary Industries, 2004. 419p.

HARRIS, C.E.; TULLBERG, J.N. Pathways of water loss from legumes and grasses cut from conservation. Grass. Forage Sci., v.35, p.1-11, 1980.

HERNÁNDEZ, F.I.L.; VALADARES FILHO, S.C.; PAULINO, M.F.; et al. Avaliação da composição de vários alimentos e determinação da cinética ruminal da proteína, utilizando o método de produção de gás e amônia in vitro. $R$. Bras. Zootec., v.31, p.243-255, 2002.

KOMAREK, A. R. A fiber bag procedure for improved efficiency of fiber analyses. J. Dairy Sci., v.76, supl.(1), p.250, 1993.

KOZLOSKI, G.V.; PEROTTONI, J.; SANCHEZ, L.M.B. Influence of regrowth age on the nutritive value of dwarf elephant grass hay (Pennisetum purpureum Schum. cv. Mott) consumed by lambs. Anim. Feed Sci. Technol., v.119, p.1-11, 2005.

KUNG, L. Subject: a review on silage additives and enzymes. 2002. Available in: <http://www.//ag.udel.edu/anfs/faculty/kung/artic les/a_review_on_silage_additives_and.htm >. Accessed in: 20 Jul. 2015.

LAVEZZO, W.; ANDRADE, J.B. Conservação de forragens: feno e silagem. In: SIMPÓSIO BRASILEIRO DE FORRAGICULTURA E PASTAGENS, 1994, Campinas. Anais... Campinas: Colégio Brasileiro de Nutrição Animal, 1994. p.105-106. 
LICITRA, G.; HERNANDEZ, T.M.; VAN SOEST, P.J. Standartization of procedures for nitrogen fractionation of ruminant feeds. Anim. Feed Sci. Technol., v.57, p.347-358, 1996.

LOPES, F.C.F.; SILVA E OLIVEIRA, J.; LANES, E.C.M. et al. Valor nutricional do triticale (Tritico secale Wittmack) para uso como silagem na Zona da Mata de Minas Gerais. Arq. Bras. Med. Vet. Zootec., v.60, p.1484-1492, 2008.

MAcDONALD, A.D.; CLARK, E.A. Water and quality loss during field drying of hay. $A d v$. Agron., v.41, p.407-437, 1987.

McDONALD, P.; HENDERSON, A.R.; HERON, S. The biochemistry of silage. 2.ed. Marlow: Chalcombe Publications, 1991. 340p.

MESQUITA, E.E.; NERES, M.A. Morfogênese e composição bromatológica de cultivares de Panicum maximum em função da adubação nitrogenada. Rev. Bras. Saúde Prod. Anim., v.9, p.201-209, 2008.

MINSON, D.J. Forage in ruminant nutrition. San Diego: Academic Press, 1990. 483p.

MUCK, R.E.; SCHINNES, K.J. Conserved forages (silage and hay): progress and priorities. In. INTERNATIONAL GRASSLAND CONGRESS, 19., 2001, São Pedro. Proceedings... Piracicaba: Brazilian Society of Animal Husbandry, 2001. p.753.

NERES, M.A.; CASTAGNARA, D.D.; MESQUITA, E.E. et al. Production of tifton 85 hay overseeded with white oats or ryegrass. Rev. Bras. Zootec., v.40, p.1638-1644-2011.

NUSSIO, L.G.; ZOPOLLATTO, M.; MOURA, J.C. Metodologia de avaliação e aditivos. WORKSHOP SOBRE MILHO PARA SILAGEM, 2., 2001, Piracicaba. Anais... Piracicaba: FEALQ, 2001.

OFFICIAL methods of analysis. 12.ed. Washington: AOAC, 1995.

OFFICIAL methods of analysis. 16.ed. Gaitherburg: AOAC, 1997.

OFFICIAL METHODS OF ANALYSIS. 16ed., 2nd ed. Maryland: AOAC, 1998.
OLIVEIRA, L.V.; FERREIRA, O.G.L.; PEDROSO, C.E.S. et al. Características estruturais de cultivares diplóides e tetraplóides de azevém. Biosci. J., v.31, p.883-889, 2015.

PEREIRA, J.R.; REIS, R.A. Produção de silagem pré-secada com forrageiras temperadas e tropicais. In: SIMPÓSIO SOBRE PRODUÇÃO E UTILIZAÇÃO DE FORRAGENS CONSERVADAS, 2001, Maringá. Anais... Maringá: UEM/CCA/DZO, 2001. p.139.

PINTO, L.F.M.; SILVA, S.C.; SBRISSIA, A.F. et al. Dinâmica do acúmulo de matéria seca em pastagens de tifton 85 sob pastejo. Sci. Agric., v.58, p.439-447, 2001.

SENGER, C.C.D.; KOZLOSKI, G.V.; SANCHEZ, L.M.B. et al. Evaluation of autoclave procedures for fibre analysis in forage and concentrate feedstuffs. Anim. Feed Sci. Technol., v.146, p.169-174, 2008.

SILVA, D.J.; QUEIROZ, A.C. Análises de alimentos (métodos químicos e biológicos). 3.ed. Viçosa, MG: UFV, 2002. 235p.

SKONIESKI, F.R.; VIÉGAS, J.; BERMUDES, R.F. et al. Composição botânica e estrutural e valor nutricional de pastagens de azevém consorciadas. Rev. Bras. Zootec., v.40, p.550556, 2011.

STRECK, E.V.; KÄMPF, N.; DALMOLIN, R.S.D. et al. Solos do Rio Grande do Sul. 2.ed. Porto Alegre: Emater/RS, 2008. 222p.

VAN SOEST, P.J. Nutritional ecology of the ruminant. 2.ed. Ithaca: Cornell University, 1994. 476p.

VAN SOEST, P.J. Use of detergents in the analysis of fibrous foods. II. A rapid method for the determination of fibre and lignin. J. Assoc. Off. Anal. Chem., v.46, p.829-835, 1963.

VANBELLE, M.; ARNOULD, R.; DEWYSEN, A. et al. Inkuilen een actueel probleem. Leuven: Iwonl, 1983. 81p.

WOOLFORD, M.K. The silage fermentation. New York: Marcel Dekker, 1984. 350p. 